DOI: $10.5433 / 1679-0359.2018 v 39 n 3 p 1143$

\title{
Do fibrolytic, proteolytic and amylolytic enzymes influence the in vitro fermentation characteristics of forage?
}

\section{Enzimas fibrolíticas, amilolíticas e proteolíticas influenciam as características de fermentação in vitro de forragem?}

\author{
Lucien Bissi da Freiria ${ }^{1 *}$; Joanis Tilemahos Zervoudakis ${ }^{2}$; Nelcino Franciso de \\ Paula $^{2}$; Luciano da Silva Cabral2 ${ }^{2}$ Luis Orlindo Tedeschi³ ${ }^{3}$ Pedro Ivo José Lopes da \\ Rosa e Silva ${ }^{1}$; Alan Carlos Barboza Melo ${ }^{4}$; Adriano Jorge Possamai ${ }^{1}$
}

\begin{abstract}
The effects of increasing doses of three exogenous enzymes preparations with fibrolytic activity (FIB - 0, 0.6, 1.2, 1.8, and $2.4 \mathrm{mg} \mathrm{mL}^{-1}$ liquid volume incubated), amylolytic activity (AMZ - 0, 0.05, 0.10, 0.15 , and $0.20 \mathrm{mg} \mathrm{mL}^{-1}$ liquid volume incubated), and proteolytic activity (PRO - 0, 0.05, 0.10, 0.15, and $0.20 \mathrm{mg} \mathrm{mL}^{-1}$ liquid volume incubated ) on gas production (GP), kinetic parameters, and fermentation profile of Brachiaria brizantha $\mathrm{cv}$. Marandu were evaluated using the in vitro gas production technique. Ruminal liquid was obtained from two rumen-cannulated Santa Inês sheep maintained on pasture. Accumulated gas production was measured during 96 hours of incubation, measured at 18 different time points. The determined parameters were $\mathrm{pH}$, asymptotic gas production $\left(\mathrm{mL} \mathrm{g}^{-1}\right)$, rate of gas production $\left(\mathrm{h}^{-1}\right)$, lag time (h), organic matter digestibility (OMD, $\left.\mathrm{g} \mathrm{g}^{-1} \mathrm{DM}\right)$, metabolizable energy (ME, MJ kg-1 $\mathrm{DM}$ ), and neutral detergent fiber digestibility (NDFD, $\mathrm{mg} \mathrm{g}^{-1} \mathrm{DM}$ ). Increasing the FIB dose linearly increased $(\mathrm{P}<0.05)$ the asymptotic gas production. However, the rate of gas production and the lag time showed linear decreases $(\mathrm{P}<0.05)$. Addition of FIB also linearly increased $(\mathrm{P}<0.05)$ the GP at all incubation times, as well as the OMD, NDFD and ME. Addition of AMZ linearly increased $(\mathrm{P}<$ $0.05)$ the asymptotic gas production, but GP linear increased $(\mathrm{P}<0.05)$ only at the 6-hour and 12 -hour time points. The rate of gas production and the lag time decreased linearly $(\mathrm{P}<0.05)$ in response to increasing $\mathrm{AMZ}$ addition. Inclusion of PRO did not affect $(\mathrm{P}>0.05)$ asymptotic gas production, but there was quadratic effect $(\mathrm{P}<0.05)$ on the rate of gas production, the lag time, and the GP at the 6-hour and 12-hour time points. The OMD, NDFD and ME were not affected by PRO addition. Thus, fibrolytic, amylolytic and proteolytic enzymes are effective in reducing the lag time and increasing the in vitro gas production from Brachiaria Brizantha cv. Marandu forage, and fibrolytic enzymes improve the in vitro fermentation profile.
\end{abstract}

Key words: Digestibility. Gas production. Rumen liquor.

\footnotetext{
1 Discentes, Universidade Federal de Mato Grosso, UFMT, Cuiabá, MT, Brasil. E-mail: lucienbissi@hotmail.com; pedroivocba@hotmail.com; adrianojorgepossamai@hotmail.com

2 Profs., UFMT, Cuiabá, MT, Brasil. E-mail: joanis@ufmt.br; nelcinodepaula@hotmail.com; lucianoufmt@gmail.com

3 Prof., Texas A\&M University, Department of Animal Science, TAMU, College Station, TX, Estados Unidos. E-mail: luis. tedeschi@tamu.edu

4 M.e, em Ciência Animal, UFMT, Cuiabá, MT, Brasil. E-mail: allan.a.b@hotmail.com

* Author for correspondence
} 


\section{Resumo}

Avaliou-se os efeitos de doses crescentes de três enzimas exógenas: fibrolíticas (FIB), 0; 0,6;1,2;1,8 e 2,4 $\mathrm{mg} \mathrm{mL}^{-1}$ volume de líquido incubado; amilolíticas (AMZ), $0 ; 0,05 ; 0,10 ; 0,15$ e $0,20 \mathrm{mg} \mathrm{mL}^{-1}$ volume de líquido incubado, proteolíticas (PRO), $0 ; 0,05 ; 0,10 ; 0,15$ e $0,20 \mathrm{mg} \mathrm{mL}^{-1}$ volume de líquido incubado, sobre a produção de gases (PG), parâmetros cinéticos e perfil da fermentação da Brachiaria brizantha cv. Marandu usando a técnica in vitro de produção de gases. O líquido ruminal foi obtido de dois ovinos Santa Inês canulados no rúmen, mantidos em regime de pastejo. A produção de gases acumulada foi obtida durante $96 \mathrm{~h} 00$ de incubação, mensurada em 18 tempos. Ao final da incubação foram determinados o $\mathrm{pH}$, produção de gás assintótica $\left(\mathrm{mL} \mathrm{g}^{-1}\right)$, taxa de degradação fracional $\left(\mathrm{h}^{-1}\right)$, lag time (h), digestibilidade da matéria orgânica (DMO, g/g MS incubada por 24h00), energia metabolizável (EM, MJ kg-1 MS) e a digestibilidade da fibra insolúvel em detergente neutro (DFDN, $\mathrm{mg} \mathrm{g}^{-1} \mathrm{MS}$ ). As doses de FIB aumentaram linearmente $(\mathrm{P}<0,05)$ a produção de gases assintótica. Entretanto, a taxa de degradação fracional e lag time reduziram linearmente $(\mathrm{P}<0,05)$. A adição de FIB também aumentou linearmente $(\mathrm{P}<0,05)$ a $\mathrm{PG}$ em todos os tempos de incubação, DMO, DFDN e EM. A inclusão de AMZ aumentou linearmente $(\mathrm{P}<0,05)$ a produção de gases assintótica, e a $\mathrm{PG}$ somente nos tempos 6 e 12 horas após a incubação. A taxa de degradação fracional e lag time reduziu linearmente $(\mathrm{P}<0,05)$ com a inclusão de AMZ. A inclusão de PRO não modificou $(P>0,05)$ a produção de gás assintótica, mas promoveu efeito quadrático $(\mathrm{P}<0,05)$ na taxa de degradação fracional, lag time, e $\mathrm{PG}$ nos tempos $6 \mathrm{e}$ 12. No entanto, PRO não afetou DMO, DFDN e EM. As enzimas fibrolíticas, amilolíticas e proteolíticas são efetivas em reduzir o lag time e aumentar a produção de gases in vitro da Brachiaria Brizantha cv. Marandu, e as enzimas fibrolíticas melhoram o perfil da fermentação in vitro.

Palavras-chave: Digestibilidade. Produção de gás. Líquido ruminal.

\section{Introduction}

Forage constitutes an important part of the diet in most ruminant production systems (GIRALDO et al., 2008). Physiologically, forage structure is defined by the presence of cell walls and cellular contents, which have great agronomic importance (HATFIELD, 1989). In ruminant feed, forage can be classified according to its nutritional qualities, which must be considered relative to the digestion process. There are two conceptual nutritional components in forage: fibrous carbohydrates (cellulose, hemicellulose and lignin), which have a lower ruminal digestion rate $\left(0.05 \mathrm{~h}^{-1}\right)$; and nonfibrous carbohydrates (starch, sugars and pectin) which are digested faster $\left(0.15 \mathrm{~h}^{-1}\right)$ (MERTENS, 1996).

The proportion of fibrous carbohydrates can range from 20 to $80 \%$ of the dry matter in forage, according to the characteristics of the plant material (WILSON, 1994), and this proportion may negatively impact ingestion and digestibility
(MINSON, 1990). According to Moore and Mott (1973), the fiber content is lower in leaves compared with stems, in young plants compared with mature plants, in legumes compared with grasses, and in temperate $\left(\mathrm{C}_{3}\right)$ compared with tropical grasses $\left(\mathrm{C}_{4}\right)$.

Notably, Brazilian pasture cattle production systems make extensive use of $\mathrm{C}_{4}$ grasses, with their characteristic high fiber content directly influencing the intake and digestibility of their components. Use of these $\mathrm{C}_{4}$ grasses may cause a restriction in nutrient availability for ruminal microbial growth (ADESOGAN et al., 2014; MEALE et al., 2014), in turn limiting microbial production of enzymes related to food degradation.

Thus, studies that include exogenous enzyme compounds in animal diets containing fibrous food have shown great potential in ruminant production (RANILLA et al., 2008; MEALE et al., 2014). Exogenous enzymes improve production by improving the nutritional value of forage and the efficiency of its use, by releasing nutrients 
complexed with the plant cell walls (TANG et al., 2008; ELGHANDOUR et al., 2013). However, in some cases, the use of exogenous enzymes has not shown benefits in fiber degradation (KNOWLTON et al., 2002; AVELLANEDA et al., 2009).

Thus, it is necessary to evaluate the potential of using exogenous enzymes with fibrous animal feeds. For this purpose, the in vitro fermentation technique can be used to measure the production of gases using semi-automatic (THEODOROU et al., 1994; MAURÍCIO et al., 1999) or computerized methods (TEDESCHI et al., 2009). This technique allows the evaluation of kinetic degradation parameters such as rate and extension in the fermentation (VÁRADYOVÁ et al., 2005; ELGHANDOUR et al., 2013), and is applicable to large numbers of samples in a short period of time (MAURÍCIO et al., 2003). It can thus be used to understand the effects of including exogenous enzymes in the ruminant feed, allowing the identification of the most appropriate enzymes and their respective optimum levels of inclusion in ruminant diets (EUN; BEAUCHEMIN, 2007).

The objective of this study was to evaluate the effects of different doses of exogenous enzymatic complexes with fibrolytic, amylolytic and proteolytic activity on gas production, kinetic parameters and in vitro fermentation profiles using Brachiaria brizantha cv. Marandu forage as the substrate.

\section{Materials and Methods}

\section{Forage and preparation of enzymes}

The forage used as the substrate in in vitro incubations was Brachiaria Brizantha cv. Marandu. The samples were obtained in January by means of manual grazing simulation (hand plucking) in different regions of Mato Grosso state, Brazil (Table 1).

Table 1. Chemical composition of Brachiaria Brizantha cv. Marandu forage. Samples were obtained in January by means of manual simulation of grazing (hand plucking) in different regions of Mato Grosso state, Brazil.

\begin{tabular}{lccc}
\hline Item & No. repetitions & $\mathrm{g} \mathrm{kg}^{-1}$ & $\mathrm{SDM}$ \\
\hline Dry matter & 5 & 285.1 & 1.45 \\
Organic matter & 5 & 930.2 & 2.15 \\
Crude protein & 5 & 108.7 & 2.23 \\
Neutral detergent insoluble fiber & 5 & 608.5 & 0.79 \\
Neutral detergent insoluble protein & 5 & 41.3 & 1.09 \\
Acid detergent insoluble protein & 5 & 18.4 & 0.50 \\
\hline
\end{tabular}

SDM standard deviation of the mean.

Samples of the forage were dried using forced ventilation $\left(55^{\circ} \mathrm{C}\right.$ for $\left.72 \mathrm{~h}\right)$, processed in a Willey mill with a $1.0 \mathrm{~mm}$ size screen, and stored for further determination of their chemical components and use in in vitro fermentation experiments.

Five different doses of each enzyme were evaluated according to their activity. For fibrolytic enzymes (FIB; Fibroyme, Alltech Inc.,
Nicholasville, KY) doses of 0, 0.6, 1.2, 1.8 and 2.4 $\mathrm{mg} \mathrm{mL} \mathrm{m}^{-1}$ volume of incubated liquid were used; for amylolytic enzymes (AMZ; Amaize, Alltech Inc., Nicholasville, KY) the doses were $0,0.05,0.10$, 0.15 and $0.20 \mathrm{mg} \mathrm{mL}^{-1}$ volume of incubated liquid, and for proteolytic enzymes (PRO; VEG PRO, Alltech Inc., Nicholasville, KY), 0, 0.05, 0.10, 0.15 and $0.20 \mathrm{mg} \mathrm{mL}^{-1}$ was included per in the incubated liquid. These levels were defined according to the 
manufacturer's recommendations for the daily intake for beef cattle, and extrapolated for in vitro incubation following Tricarico et al. (2005), by calculating the amount of enzyme in relation to the liquid medium (concentration $\mathrm{mg} \mathrm{mL}^{-1}$ volume of incubated liquid), not necessarily according to the enzyme:substrate ratio.

\section{Incubation in vitro}

The ruminal inoculum was collected from two Santa Inês sheep (60-70 kg body weight) with permanent ruminal cannula. The animals were kept in a paddock stocked with Brachiaria Brizantha cv. Marandu.

The ruminal content of each animal was collected at $05 \mathrm{~h} 00$, filtered through four layers of cheesecloth and placed in a thermos bottle without head space, before being sent to the Laboratory of Animal Nutrition at the Universidade Federal de Mato Grosso. In each experimental $125 \mathrm{~mL}$ serum bottle, $0.5 \mathrm{~g}$ of forage was placed, along with the enzyme doses mentioned above. Afterwards, $40 \mathrm{~mL}$ of buffer solution was added to each serum bottle according to Goering and Van Soest (1970), with 10 $\mathrm{mL}$ of ruminal liquid free of particles, a proportion of 1:4 $\left(\mathrm{v} \mathrm{v}^{-1}\right)$. The serum bottles were immediately closed with rubber stoppers and sealed with aluminum washers, before being incubated at $39^{\circ} \mathrm{C}$ in a water bath with constant agitation (MAURÍCIO et al., 1999).

A total of 126 serum bottles were used comprising triplicate samples at each enzymatic dose and control samples containing only ruminal liquid and buffer solution. Incubations were performed in three different weeks. The volume of gas produced was recorded after 1, 2, 3, 4, 5, 6, 8, 10, 12, 18, 24, 30, $36,42,48,60,72$ and 96 hours of incubation, using the semi-automatic reading technique described by Theodorou et al. (1994) and Mauricio et al. (1999). At the end of the incubation, the flasks were opened to measure the $\mathrm{pH}$ (peagâmetro, $\mathrm{pH}$ METER TC2, Tecnal), and subsequently the contents were filtered to obtain the unfermented residue in order to determine the amount of digested substrate.

\section{In vitro digestibility of neutral detergent insoluble} fiber

After the incubation the serum bottles were opened and the $\mathrm{pH}$ of the contents measured. Then, $40 \mathrm{~mL}$ per flask (MERTENS, 2002) of neutral detergent solution was added (VAN SOEST et al., 1991). The flasks were then autoclaved according to method described by Pell and Schofield (1993). After autoclaving, the contents of each flask were filtered through a filter crucible (porosity $n^{\circ} .2,40$ $100 \mu \mathrm{m})$. After filtration, the NDF residues were oven dried at $105{ }^{\circ} \mathrm{C}$ for 16 hours and weighed to estimate the in vitro digestibility of neutral detergent insoluble fiber (NDFD).

\section{Chemical analysis of feed and enzymatic activity}

Samples of the forage were analyzed in accordance with AOAC procedures (AOAC, 1990) for dry matter (DM, method no. 930.15), ash (method no. 924.05), and crude protein (CP, method no. 984.13). NFD was determined by the method of Van Soest et al. (1991).

The fibrolytic enzyme preparation comprising xylanase (583 XU g ${ }^{-1}$ ) and cellulase (163 CMCU $\mathrm{g}^{-1}$ ) activities (FibrozymeTM, Alltech Inc., Nicholasville, KY, USA) was previously checked using the methodologies of Colombatto and Beauchemin (2003). Amylolytic enzyme activity (amylase min $600 \mathrm{FAU} \mathrm{g}^{-1}$ ) was checked following Biely et al. (1985) and Tricarico et al. (2008) and the activity of the proteolytic enzyme preparation (protease $\min 7.500 \mathrm{u}$ HUT $\mathrm{g}^{-1}$ and cellulase min $45 \mathrm{u} \mathrm{CMCU} \mathrm{g}^{-1}$ ) was confirmed using methods in the Food Chemicals Codex (2010). 


\section{Calculations}

The kinetic parameters of gas production $\left(\mathrm{mL} \mathrm{g}^{-1}\right.$ DM) were estimated using the PROC NLIN method in SAS (2011), according to the model proposed by Lavrencic et al. (1997):

$$
y=a x \exp (-\mathrm{C} * \exp (-A x t))
$$

where $a$ is the asymptotic gas production $(\mathrm{mL}), \mathrm{C}$ is the constant rate of gas production of potentially degradable material $\left(\mathrm{h}^{-1}\right), \mathrm{A}$ is a constant factor of microbial efficiency (h) and $t$ is the time of incubation (h).

Metabolizable energy ( $\left.\mathrm{ME}, \mathrm{MJ} \mathrm{kg}^{-1} \mathrm{DM}\right)$ and in vitro digestibility of organic matter (OMD, $\mathrm{g}$ $\mathrm{kg}^{-1} \mathrm{OM}$ ) were estimated according to Menke et al. (1979):

$M E=2.20+0.136 G P(m l / 0.2 g D M)+0.057 C P(m g / 0.2 g D M)$

$O M D=148.8+8.89 G P+4.5 G P(m g / 0.2 g D M)+0.651 \mathrm{ash}(\mathrm{mg} / 0.2 \mathrm{~g} D M)$

where GP is the gas production in $\mathrm{mL}$ per $200 \mathrm{mg}$ of dry sample incubated for 24 hours.

\section{Statistical analysis}

The in vitro parameters of gas production and the fermentation profile were analyzed considering a completely randomized design using the PROC MIXED method in SAS (2011). The model used was:

$$
Y_{i j}=\mu+E N Z_{i}+\varepsilon_{i j}
$$

where $Y_{i j}$ is the dependent variable, $\mu$ is the overall mean, $\mathrm{ENZ}_{\mathrm{i}}$ is the effect of the level of inclusion of exogenous enzymes, and $\mathrm{E}_{\mathrm{ij}}$ is the residual error.

The levels of the enzyme preparations were considered as fixed effects. Before statistical analysis, the mean was obtained from the data of each week, which was used as experimental unit (UDÉN et al., 2012). The option LSMEANS was used to generate individual means for each treatment. Orthogonal contrasts were used to partition the effects of enzyme levels into linear, quadratic, cubic, and quartic effects. Due to a lack of cubic and quartic effects, these were removed from the tables. In all analyses, significance was considered when $\mathrm{P}<0.05$.

\section{Results and Discussion}

The addition of FIB increased the asymptotic gas production $(\mathrm{P}<0.05)$, and linearly decreased the rate of fractional degradation $(\mathrm{P}<0.05)$ and the lag time $(\mathrm{P}<0.05)$ (Table 2). Larger doses in FIB resulted in linear increases $(\mathrm{P}<0.05)$ in $\mathrm{GP}$ at all time points evaluated (Table 2 and Figure 1a). Increasing doses of $\mathrm{AMZ}$ resulted in linear increases in asymptotic gas production $(\mathrm{P}<0.05)$, and linear reductions in the rate of fractional degradation and the lag time $(\mathrm{P}<0.05)$ (Table 2). However, linear increases in GP $(\mathrm{P}<0.05)$, only occurred at the 6 and 12 hour time points $\left(\mathrm{GP}_{6}\right.$ and $\left.\mathrm{GP}_{12}\right)$ (Table 2 and Figure $\left.1 \mathrm{~b}\right)$. The inclusion of PRO did not change $(\mathrm{P}>0.05)$ the asymptotic gas production, but resulted in linear decreases in the rate of degradation and lag time $(\mathrm{P}<0.05)$. Similar to enzyme AMZ, increased doses of PRO only resulted in linear increases in GP at the 6 and 12 hour time points $(\mathrm{P}<0.05)$ (Table 2 and Figure 1c).

None of the enzyme additions (FIB, AMZ or $\mathrm{PRO}$ ) changed the $\mathrm{pH}$ at the end of the incubation $(\mathrm{P}>0.05)$ (Table 3).

The benefits promoted by the addition of the FIB enzyme mix in terms of the kinetic parameters and the production of accumulated gases, can be understood as interaction effects between ruminal microorganisms and the enzymes. The presence of the enzymes in the ruminal substrate releases polysaccharides that are readily used by microorganisms (TRICARICO et al., 2008), increasing the number of fibrolytic and nonfibrolytic bacteria, and promoting biofilm formation in the fibrous material (EDWARDS et al., 2007). This improves the ruminal fermentation efficiency (NSEREKO et al., 2002), resulting in an increase in the ruminal hydrolytic capacity (ADESOGAN, 2005). The reduction of the lag time, may be a result 
of the FIB enzyme promoting increased colonization of plant cell walls in the forage material (NSEREKO et al., 2002). Its enzymatic activity acts on fibrous compounds that are more slowly digested, reducing the time needed for the bacteria to adhere to the food material (SUTTON et al., 2003). This has the effect of increasing the rate of in vitro digestion, and also the extent of NDF and MO digestion in vitro, as observed in this experiment. The benefits observed with the addition of the FIB enzyme preparation are in agreement with the results reported by Giraldo et al. (2008) and Tang et al. (2008).

Table 2. Ruminal kinetic parameters of gas production and accumulation after 96 hours of incubation showing the effects of exogenous enzyme levels ( $\mathrm{mg} \mathrm{mL}^{-1}$ volume of incubated liquid).

\begin{tabular}{|c|c|c|c|c|c|c|c|c|c|c|}
\hline \multirow{2}{*}{$\begin{array}{l}\text { Dose } \\
\text { Enzyme }\end{array}$} & \multicolumn{4}{|c|}{${ }^{\text {aParameters of gas production }}$} & \multicolumn{6}{|c|}{ in vitro gas production $\left(\mathrm{mL} \mathrm{g}^{-1} \mathrm{DM}\right)$} \\
\hline & $A$ & $B$ & $L$ & $\operatorname{Pr}>F^{b}$ & GP6 & GP12 & GP24 & GP48 & GP72 & GP96 \\
\hline \multicolumn{11}{|c|}{ Fibrolytic Enzyme } \\
\hline 0.0 & 248.7 & 0.048 & 10.74 & $<0.001$ & 13.2 & 21.2 & 53.8 & 162.0 & 216.4 & 235.5 \\
\hline 0.6 & 264.8 & 0.044 & 7.29 & $<0.001$ & 19.8 & 30.9 & 65.9 & 172.3 & 227.9 & 247.0 \\
\hline 1.2 & 284.5 & 0.042 & 3.54 & $<0.001$ & 30.4 & 43.4 & 82.0 & 190.2 & 245.4 & 263.4 \\
\hline 1.8 & 298.9 & 0.042 & 1.55 & $<0.001$ & 37.1 & 52.9 & 95.6 & 204.2 & 260.3 & 278.1 \\
\hline 2.4 & 312.6 & 0.042 & 0.09 & $<0.001$ & 44.2 & 62.3 & 109.0 & 220.4 & 275.9 & 293.1 \\
\hline SEM & 10.27 & 0.002 & 0.97 & & 2.59 & 2.93 & 5.62 & 8.70 & 7.67 & 7.87 \\
\hline Linear $^{\mathrm{c}}$ & 0.001 & 0.010 & $<0.001$ & & $<0.001$ & $<0.001$ & $<0.001$ & $<0.001$ & $<0.001$ & $<0.001$ \\
\hline Quadratic & 0.796 & 0.069 & 0.146 & & 0.774 & 0.748 & 0.996 & 0.815 & 0.851 & 0.859 \\
\hline \multicolumn{11}{|c|}{ Amylolytic Enzyme } \\
\hline 0.00 & 248.7 & 0.048 & 10.74 & $<0.001$ & 13.2 & 21.2 & 53.8 & 162.0 & 216.4 & 235.5 \\
\hline 0.05 & 268.3 & 0.043 & 6.35 & $<0.001$ & 23.0 & 31.7 & 65.9 & 176.1 & 229.2 & 248.5 \\
\hline 0.10 & 270.4 & 0.042 & 5.64 & $<0.001$ & 24.8 & 33.3 & 67.8 & 177.8 & 230.6 & 249.5 \\
\hline 0.15 & 274.6 & 0.041 & 5.35 & $<0.001$ & 25.7 & 34.2 & 68.3 & 177.4 & 232.0 & 251.4 \\
\hline 0.20 & 277.3 & 0.040 & 4.06 & $<0.001$ & 29.1 & 37.5 & 71.2 & 180.3 & 233.3 & 252.7 \\
\hline SEM & 7.88 & 0.001 & 1.18 & $<0.001$ & 2.15 & 2.20 & 6.82 & 6.97 & 5.85 & 6.04 \\
\hline Linear $^{\mathrm{d}}$ & 0.029 & $<0.001$ & 0.003 & & $<0.001$ & $<0.001$ & 0.115 & 0.115 & 0.076 & 0.078 \\
\hline Quadratic & 0.305 & 0.097 & 0.166 & & 0.117 & 0.094 & 0.450 & 0.372 & 0.316 & 0.347 \\
\hline \multicolumn{11}{|c|}{ Proteolytic Enzyme } \\
\hline 0.00 & 248.7 & 0.048 & 10.74 & $<0.001$ & 13.2 & 21.2 & 53.8 & 162.0 & 216.4 & 235.5 \\
\hline 0.05 & 273.8 & 0.040 & 4.90 & $<0.001$ & 26.9 & 34.7 & 67.4 & 175.6 & 229.9 & 249.2 \\
\hline 0.10 & 271.5 & 0.040 & 4.89 & $<0.001$ & 26.4 & 34.3 & 66.9 & 174.3 & 227.7 & 247.2 \\
\hline 0.15 & 272.4 & 0.040 & 4.89 & $<0.001$ & 26.5 & 34.5 & 67.4 & 174.9 & 228.8 & 248.0 \\
\hline 0.20 & 273.1 & 0.040 & 4.07 & $<0.001$ & 28.2 & 36.3 & 69.2 & 175.6 & 228.6 & 247.8 \\
\hline SEM & 8.09 & 0.002 & 0.97 & & 2.10 & 2.21 & 5.69 & 5.65 & 4.83 & 4.80 \\
\hline Linear $^{\mathrm{e}}$ & 0.098 & 0.006 & 0.002 & & 0.001 & 0.002 & 0.117 & 0.168 & 0.157 & 0.154 \\
\hline Quadratic & 0.162 & 0.270 & 0.200 & & 0.140 & 0.200 & 0.312 & 0.282 & 0.211 & 0.197 \\
\hline
\end{tabular}

${ }^{\mathrm{a}} a$ is the production of asymptotic gas $\left(\mathrm{mL} \mathrm{g}^{-1} \mathrm{DM}\right) ; b$ is rate of gas production $\left(\mathrm{h}^{-1}\right) ; L$ is lag time before gas production start $(\mathrm{h})$; SEM is the standard error of the mean. ${ }^{b}$ Value of probability of adjustment of the models to estimate the parameters in vitro gas production. ${ }^{\mathrm{c}}$ Fibrolytic, $A=249.84+27.631 \mathrm{x}\left(\mathrm{r}^{2}=0.702\right) ; B=0.046-0.0026 \mathrm{x}\left(\mathrm{r}^{2}=0.399\right) ; L=9.983-4.603 \times\left(\mathrm{r}^{2}=0.844\right) ; \mathrm{GP} 6=$ $13.267+13.52 \mathrm{x}\left(\mathrm{r}^{2}=0.889\right) ; \mathrm{GP} 12=21.507+17.784 \mathrm{x}\left(\mathrm{r}^{2}=0.914\right) ; \mathrm{GP} 24=53.46+23.968 \mathrm{x}\left(\mathrm{r}^{2}=0.851\right) ; \mathrm{GP} 48=160.31+25.458 \mathrm{x}$ $\left(\mathrm{r}^{2}=0.737\right) ; \mathrm{GP} 72=215.16+25.878 \mathrm{x}\left(\mathrm{r}^{2}=0.787\right) ; \mathrm{GP} 96=234.44+25.005 \mathrm{x}\left(\mathrm{r}^{2}=0.767\right) .{ }^{\mathrm{d}}$ Amylolytic, $A=255.15+126.71 \mathrm{x}\left(\mathrm{r}^{2}\right.$ $=0.355) ; B=0.046-0.037 \mathrm{x}\left(\mathrm{r}^{2}=0.592\right) ; L=9.302-28.733 \mathrm{x}\left(\mathrm{r}^{2}=0.516\right) ; \mathrm{GP} 6=16.298+68.68\left(\mathrm{r}^{2}=0.625\right) ; \mathrm{GP} 12=24.585+$ $70.281 \times\left(\mathrm{r}^{2}=0.613\right)$. ${ }^{\mathrm{e}}$ Proteolytic, $B=0.045-0.035 \mathrm{x}\left(\mathrm{r}^{2}=0.377\right) ; L=8.569-26.702 \mathrm{x}\left(\mathrm{r}^{2}=0.453\right) ; \mathrm{GP} 6=18.351+59.097 \mathrm{x}\left(\mathrm{r}^{2}=\right.$ $0.441) ; \mathrm{GP} 12=26.213+60.029 \mathrm{x}\left(\mathrm{r}^{2}=0.445\right)$. 
Figure 1. Profile of the accumulated gas production $\left(\mathrm{mL} \mathrm{g}^{-1} \mathrm{DM}\right)$ for in vitro ruminal fermentation with doses of exogenous enzymes (mg mL $\mathrm{mL}^{-1}$ volume of incubated liquid): a Fibrolytic enzyme; b Amylolytic enzyme; and c Proteolytic enzyme.

a)
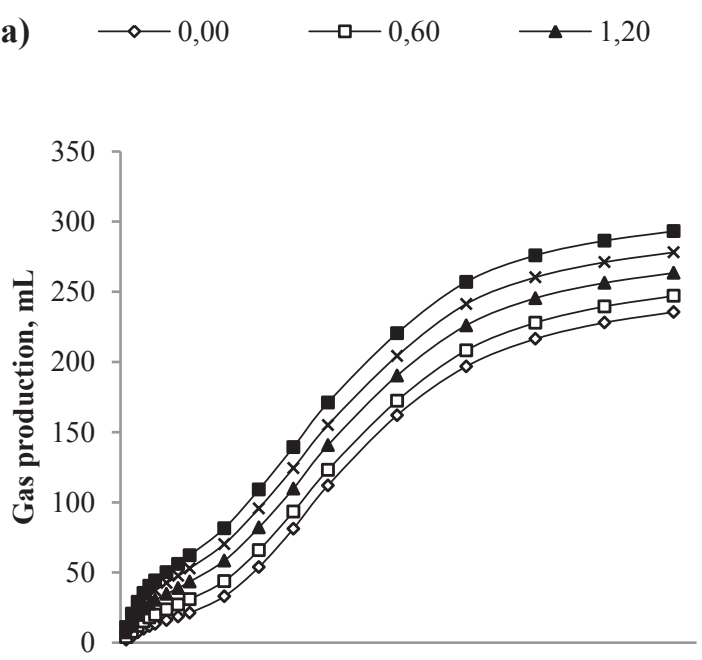

b) $\multimap 0,00 \multimap-0,05 \multimap 0,10 \multimap 0,15 \longrightarrow 0,20$

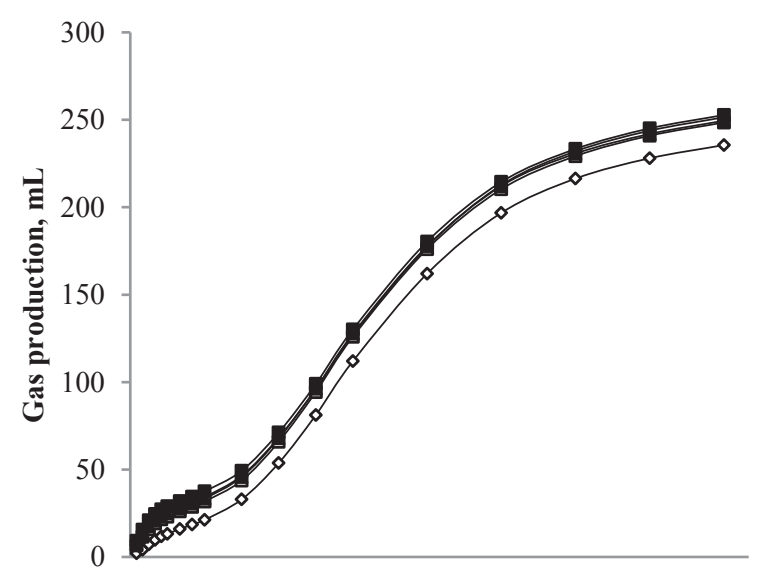

c)

$\longrightarrow 0,05 \longrightarrow 0,10$

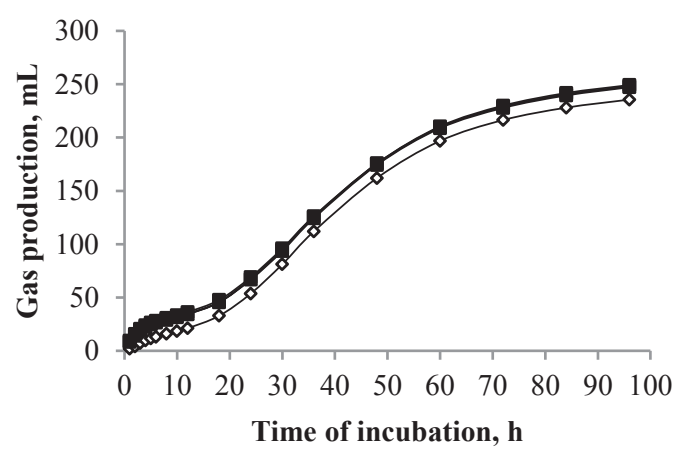


Table 3. In vitro ruminal fermentation profile ${ }^{\mathrm{a}}$ with effect of doses of exogenous enzymes $\left(\mathrm{mg} \mathrm{mL}^{-1}\right.$ volume of incubated liquid) after $96 \mathrm{~h}$ incubation.

\begin{tabular}{|c|c|c|c|c|c|c|c|c|}
\hline & \multicolumn{5}{|c|}{ Fibrolytic Enzyme } & \multirow[t]{2}{*}{ SEM } & \multirow[t]{2}{*}{ Linear $^{b}$} & \multirow[t]{2}{*}{ quadratic } \\
\hline & 0.0 & 0.6 & 1.2 & 1.8 & 2.4 & & & \\
\hline $\mathrm{pH}$ & 6.68 & 6.67 & 6.66 & 6.64 & 6.63 & 0.02 & 0.116 & 0.731 \\
\hline OMD & 0.345 & 0.366 & 0.395 & 0.420 & 0.443 & 0.01 & $<0.001$ & 0.986 \\
\hline NDFD & 0.461 & 0.492 & 0.523 & 0.555 & 0.593 & 0.06 & $<0.001$ & 0.534 \\
\hline \multirow[t]{3}{*}{ ME } & 4.82 & 5.15 & 5.59 & 5.96 & 6.32 & 0.15 & $<0.001$ & 0.991 \\
\hline & \multicolumn{5}{|c|}{ Amylolytic Enzyme } & SEM & Linear & quadratic \\
\hline & 0.00 & 0.05 & 0.10 & 0.15 & 0.20 & & & \\
\hline $\mathrm{pH}$ & 6.68 & 6.69 & 6.70 & 6.70 & 6.70 & 0.02 & 0.564 & 0.671 \\
\hline OMD & 0.345 & 0.366 & 0.370 & 0.371 & 0.376 & 0.01 & 0.112 & 0.453 \\
\hline NDFD & 0.461 & 0.464 & 0.466 & 0.461 & 0.463 & 0.05 & 0.952 & 0.702 \\
\hline \multirow[t]{3}{*}{ ME } & 4.82 & 5.15 & 5.20 & 5.21 & 5.30 & 0.18 & 0.113 & 0.457 \\
\hline & \multicolumn{5}{|c|}{ Proteolytic Enzyme } & SEM & Linear & quadratic \\
\hline & 0.00 & 0.05 & 0.10 & 0.15 & 0.20 & & & \\
\hline $\mathrm{pH}$ & 6.68 & 6.69 & 6.70 & 6.70 & 6.70 & 0.029 & 0.601 & 0.744 \\
\hline OMD & 0.345 & 0.369 & 0.368 & 0.369 & 0.372 & 0.01 & 0.111 & 0.309 \\
\hline NDFD & 0.462 & 0.461 & 0.471 & 0.462 & 0.460 & 0.06 & 0.933 & 0.381 \\
\hline ME & 4.82 & 5.19 & 5.17 & 5.19 & 5.24 & 0.15 & 0.116 & 0.318 \\
\hline
\end{tabular}

${ }^{a} \mathrm{OMD}$ is the organic matter digestibility ( $\mathrm{g} \mathrm{g}^{-1} \mathrm{DM}$ incubated at $24 \mathrm{~h}$ ); NDFD is the neutral detergent insoluble fiber digestibility $\left(\mathrm{g} \mathrm{g}^{-1} \mathrm{DM}\right)$; ME is the metabolizable energy $\left(\mathrm{MJ} \mathrm{kg}^{-1} \mathrm{DM}\right)$. SEM is the standard error of the mean.

${ }^{\mathrm{b}} \mathrm{OMD}=0.3438+0.0417 \mathrm{x}\left(\mathrm{r}^{2}=0.998\right) ; \mathrm{NDFD}=0.4603+0.056 \mathrm{x}\left(\mathrm{r}^{2}=0.959\right) ; \mathrm{ME}=4.806+0.635 \mathrm{x}\left(\mathrm{r}^{2}=0.998\right)$.

Increasing doses of FIB caused linear increases $(\mathrm{P}<0.05)$ in OMD, NFDD and ME (Table 3); however, these parameters were not influenced by the dose of AMZ or PRO ( $\mathrm{P}>0.05)$ (Table 3$)$.

Increasing doses of $\mathrm{AMZ}$ were effective in improving kinetic parameters, which potentiate the production of gas accumulated in the initial hours. Tricarico et al. (2008) found that the addition of an enzyme mix containing $\alpha$-amylase activity promotes the release of oligosaccharides from starch that may be used both by amylolytic and nonamylolytic bacteria. For this reason, the starch is rapidly fermented with greater production of gases in the initial hours, but it is present in low amounts in tropical grasses $\left(>10 \mathrm{~g} \mathrm{~kg}^{-1}\right)$.

Elghandour et al. (2013) used a multi-enzyme compound, containing endoglucanase, xylanase, protease activities and a high concentration of $\alpha$-amylase activity (61.5 units $\left.\mathrm{g}^{-1}\right)$. Included in fibrous foods, they found improvements in fermentation parameters and in gas production at the evaluated time points, as did Gado et al. (2009) using the same enzyme preparation. They evaluated fermentative parameters and productive characteristics of lactating dairy cows fed corn silage (70 $\left.\mathrm{g} \mathrm{kg}^{-1} \mathrm{DM}\right)$ and concentrate (30 g $\mathrm{kg}^{-1} \mathrm{DM}$ ), supplemented with $40 \mathrm{~g}$ cow day ${ }^{-1}$ of exogenous enzymes, and observed an increase in the consumption of DM and OM (from 16.1 to 18.2 and from 14.1 to $16.4 \mathrm{~kg} \mathrm{~d}^{-1}$, respectively), and an improvement in fiber digestibility (NDFD, from 418 to $\left.584 \mathrm{~g} \mathrm{~kg}^{-1}\right)$. Milk production increased from 12.8 to $15.7 \mathrm{~kg} \mathrm{~d}^{-1}$ with daily supplementation of the multi-enzyme preparation. These articles suggest that the addition of multi-enzyme preparations may have a greater impact on ruminal fermentation. 
The use of the PRO mixture improved the kinetic parameters, with increases in accumulated gas production in the initial hours. Proteolytic enzymes are thought to act by removing structural proteins from the cell wall, allowing faster access of rumen microorganisms to digestible substrates (COLOMBATTO; BEAUCHEMIN, 2009), which may be reflected in the shorter lag times found at the lowest level of inclusion. However, increasing doses were not effective in improving DFDN or MS at the end of the 96-hour incubation. This may be due to two factors - firstly the incubation time, because Colombatto and Beauchemin (2009) observed an increase in the digestibility of DM and NDF between 18 and 22 hours of incubation, and secondly, by the use of proteolytic enzymes in isolation, because Eun and Beauchemin (2007) concluded that the combination of proteases with polysaccharidases may promote additive or synergistic effects on fiber digestibility in forage. Such an increase was also reported by Yang et al. (2011) using combinations of enzyme activities.

\section{Conclusion}

Fibrolytic, amylolytic and proteolytic enzymes were effective in reducing the lag time and increasing the in vitro gas production from Brachiaria Brizantha cv. Marandu forage, and fibrolytic enzymes improved the in vitro fermentation profile.

\section{Acknowledgments}

The authors would like to thank CAPES (Coordenação de Aperfeiçoamento de Pessoal de Nível Superior) for financial support. Thanks are also due to the Sector of Nutrition of Beef Cattle in Pasture (Universidade Federal de Mato Grosso) and the Laboratory of the Animal Nutrition (Universidade Federal de Mato Grosso).

\section{References}

ADESOGAN, A. T. Improving forage quality and animal performance with fibrolytic enzymes. In: FLORIDA RUMINANT NUTRITION SYMPOSIUM, 2005, Gainesville. Proceedings... Gainesville: Institute of Food and Agricultural Sciences, 2005. p. 91-109.

ADESOGAN, A. T.; MA, Z. X.; ROMERO, J. J.; ARRIOLA, K. G. Ruminant nutrition symposium: improving cell wall digestion and animal performance with fibrolytic enzymes. Journal of Animal Science, Champaign, v. 92, n. 4, p. 1317-1330, 2014.

ASSOCIATION OF OFFICIAL ANALYTICAL CHEMISTS - AOAC. Official methods of analysis. $15^{\text {th }}$ Arlington: Ed. Assoc. Off. Anal. Chem., 1990.

AVELLANEDA, J. H.; PINOS-RODRÍGUEZ, J. M.; GONZÁLEZ, S. S.; BÁRCENA, R.; HERNÁNDEZ, A.; COBOS, M.; HERNÁNDEZ, D.; MONTAÑEZ, O. Effects of exogenous fibrolytic enzymes on ruminal fermentation and digestion of Guinea grass hay. Animal Feed Science and Technology, Amsterdam, v. 149, n. 1-2, p. 70-77, 2009.

BIELY, P.; MISLOVICOVA, D.; TOMAN, R. Soluble chromogenic substrates for the assay of endo-1,4$\beta$-xylanases and endo-1,4- $\beta$-glucanases. Analytical Biochemistry, San Diego, v. 144, n. 1, p. 142-146, 1985.

COLOMBATTO, D.; BEAUCHEMIN, K. A. A proposed methodology to standardize the determination of enzymatic activities present in enzyme additives used in ruminant diets. Canadian Journal of Animal Science, Sherbrooke, v. 83, n. 3, p. 559-568, 2003.

. A protease additive increases fermentation of alfalfa diets by mixed ruminal microorganisms in vitro. Journal of Animal Science, Champaign, v. 87, n. 1, p. 1097-1105, 2009.

EDWARDS, J. E.; HUWS, S.A.; KIM, E. J.; KINGSTONSMITH, A. H. Characterization of the dynamics of initial bacterial colonization of nonconserved forage in the bovine rumen. FEMS Microbiology and Ecology, Oxford, v. 62, n. 1, p. 323-335, 2007.

ELGHANDOUR, M. M. Y.; SALEMA, A. Z. M.; GONZALEZ-RONQUILLOA, M.; BÓRQUEZA, J. L.; GADOB, H. M.; ODONGOC, N. E.; PENUELASA, C. G. Effects of exogenous enzymes on in vitro gas production kinetics and ruminal fermentation of four fibrous feeds. Animal Feed Science and Technology, Amsterdam, v. 179, n. 1-4, p. 46-53, 2013.

EUN, J. S.; BEAUCHEMIN, K. A. Enhancing in vitro degradation of alfalfa hay and corn silage using feed enzymes. Journal of Dairy Science, Champaign, v. 90, n. 3, p. 2839-2851, 2007. 
FOOD CHEMICALS CODEX - FCC. United states pharmacopeial convention. $7^{\text {th }}$ ed. Washington: National Academy Press, 2010. 776 p.

GADO, H. M.; SALEM, A. Z. M.; ROBINSON, P. H.; HASSAN, M. Influence of exogenous enzymes on nutrient digestibility, extent of ruminal fermentation as well as milk production and composition in dairy cows. Animal Feed Science and Technology, Amsterdam, v. 154, n. 1-2, p. 36-46, 2009.

GIRALDO, L. A.; TEJIDO, M. L.; RANILLA, M. J.; RAMOS, S.; CARRO, M. D. Influence of direct-fed fibrolytic enzymes on diet digestibility and ruminal activity in sheep fed a grass hay-based diet. Journal of Animal Science, Champaign, v. 86, n. 7, p. 1617-1623, 2008.

GOERING, M. K.; VAN SOEST, P. J. Forage fiber analysis (apparatus, reagents, procedures and some applications). In: Agriculture handbook. Washington: Ed. Agricultural Research Service, USDA, 1970, n. 379, p. 1-20.

HATFIELD, R. D. Structural polysaccharides in forages and their degradability. Agronomy Journal, Madison, v. 81, n. 1, p. 39-46, 1989.

KNOWLTON, K. F.; MCKINNEY, J. M.; COBB, C. Effect of a direct-fed fibrolytic enzyme formulation on nutrient intake, partitioning, and excretion in early and late lactation Holstein cows. Journal of Dairy Science, Champaign, v. 85, n. 12, p. 3328-3335, 2002.

LAVRENCIC, A.; STEFANON, B.; SUSMEL, P. An evaluation of the Gompertz model in degradability studies of forage chemical components. Animal Science, Liverpool, v. 64, n. 3, p. 423-431, 1997.

MAURÍCIO, R. M.; MOULD, F. L.; DHANOA, M. S.; OWEN, E.; CHANNA, K. S.; THEODOROU, M. K. A semi-automated in vitro gas production technique for ruminant feedstuff evaluation. Animal Feed Science and Technology, Amsterdam, v. 79, n. 4, p. 321-330, 1999.

MAURÍCIO, R. M.; PEREIRA, L. G. R.; GONÇALVES, L. C.; RODRIGUEZ, N. M.; MARTINS, R. G. R.; RODRIGUES, J. A. S. Potencial da técnica in vitro semi-automática de produção de gases para avaliação de silagens de sorgo (Sorghum bicolor (L.) Moench). Revista Brasileira de Zootecnia, Viçosa, MG, v. 32, n. 4, p. 1013-1020, 2003.

MEALE, S. J.; BEAUCHEMIN, K. A.; HRISTOV, A. N.; CHAVES, A. V.; MCALLISTER, T. A. BOARDINVITED REVIEW: opportunities and challenges in using exogenous enzymes to improve ruminant production. Journal of Animal Science, Champaign, v. 92, n. 2, p. 427-442, 2014.
MENKE, K. H.; RAAB, L.; SALEWSKI, A.; STEINGASS, H.; FRITZ, D.; SCHNEIDER, W. The estimation of the digestibility and metabolizable energy content of ruminant feeding stuffs from the gas production when they are incubated with rumen liquor in vitro. The Journal of Agricultural Science, London, v. 93, n. 1, p. 217-222, 1979.

MERTENS, D. Gravimetric determination of amylasetreated neutral detergent fiber in feeds with refluxing in beakers or crucibles: Collaborative study. Journal of AOAC International, Virginia, v. 85, n. 6, p. 1217-1240, 2002.

Using fiber and carbohydrate analyses to formulate dairy rations. In: INFORMATIONAL CONFERENCE WITH DAIRY AND FORAGE INDUSTRIES, 1996, Virginia. Proceedings... Virginia: Dairy Forage Research Center, 1996. p. 81-92.

MINSON, D. J. Forage in ruminant nutrition. New York: Academic Press, 1990. 483 p.

MOORE, J. E.; MOTT, G. O. Structural inhibitors of quality in tropical grasses. In: MARTCHES, A. G. Anti-quality components of forages. Madison: Ed. Crop Science Society of America, CSSA, 1973, p. 53-98.

NSEREKO, V. L.; BEAUCHEMIN, K. A.; MORGAVI, D. P.; RODE, L. M.; FURTADO, A. F.; MCALLISTER, T. A.; IWAASA, A. D.; YANG, W. Z.; WANG, Y. Effect of a fibrolytic enzyme preparation from Trichoderma longibrachiatum on the rumen microbial population of dairy cows. Canadian Journal of Microbiology, Ottawa, v. 48, n. 1, p. 14-20, 2002.

PELL, A. N.; SCHOFIELD, P. Computerized monitoring of gas production to measure forage digestion in vitro. Journal of Dairy Science, Champaign, v. 76, n. 9, p. 1063-1073, 1993.

RANILLA, M. J.; TEJIDO, M. L.; GIRALDO, L. A.; TRICÁRICO, J. M.; CARRO, M. D. Effects of an exogenous fibrolytic enzyme preparation on in vitro ruminal fermentation of three forages and their isolated cell walls. Animal Feed Science and Technology, Amsterdam, v. 145, n. 1-4, p. 109-121, 2008.

STATISTICAL ANALYSIS SYSTEM INSTITUTE - SAS. The statistical analysis system for Windows. Version 9.3. North Carolina, Ed:Cary, 2011. CD-ROM.

SUTTON, J. D.; PHIPPS, R. H.; BEEVER, D. E.; HUMPHRIES, D. J.; HARTNELL, G. F.; VICINI, J. L.; HARD, D. L. Effect of method of application of a fibrolytic enzyme product on digestive processes and milk production in Holstein-Friesian cows. Journal of Dairy Science, Champaign, v. 86, n. 2, p. 546-556, 2003. 
TANG, S. X.; TAYO, G. O.; TAN, Z. L.; SUN, Z. H.; SHEN, L. X.; ZHOU, C. S.; XIAO, W. J.; REN, G. P.; HAN, X. F.; SHEN, S. B. Effects of yeast culture and fibrolytic enzyme supplementation on in vitro fermentation characteristics of low-quality cereal straws. Journal of Animal Science, Champaign, v. 86, n. 5, p. 1164-1172, 2008.

TEDESCHI, L. O.; KONONOFF, P. J.; KARGES, K.; GIBSON, M. L. Effects of chemical composition variation on the dynamics of ruminal fermentation and biological value of corn milling (co)products. Journal of Dairy Science, Champaign, v. 92, n. 1, p. 401-413, 2009.

THEODOROU, M. K.; WILLIAMS, B. A.; DHANOA, M. S.; MCALLAN, A. B.; FRANCE, J. A simple gas production method using a pressure transducer to determine the fermentation kinetics of ruminant feeds. Animal Feed Science and Technology, Amsterdam, v. 48, n. 3-4, p. 185-197, 1994.

TRICARICO, J. M; JOHNSTON, J. D.; DAWSON, K. A. Dietary supplementation of ruminant diets with an Aspergillus oryzae $\alpha$-amylase. Animal Feed Science and Technology, Amsterdam, v. 145, n. 1-4, p. 136-150, 2008.

TRICARICO, J. M.; JOHNSTON, J. D.; DAWSON, K. A.; HANSON, K. C.; MCLEOD, K. R.; HARMON, D. L. The effects of an Aspergillus oryzae extract containing alpha-amylase activity on ruminal fermentation and milk production in lactating Holstein cows. Animal Science, Penicuik, v. 81, n. 3, p. 365-374, 2005.

UDÉN, P.; ROBINSON, P. H.; MATEOS, G. G.; BLANK, R. Use of replicates in statistical analyses in papers submitted for publication in Animal Feed Science and Technology. Animal Feed Science and Technology, Amsterdam, v. 171, n. 1, p. 11-15, 2012.

VAN SOEST, P. J.; ROBERTSON, J. B.; LEWIS, B. A. Methods for dietary fiber, neutral detergent fiber, and nonstarch polysaccharides in relation to animal nutrition. Journal of Dairy Science, Champaign, v. 74, n. 10, p. 3583-3597, 1991.

VÁRADYOVÁ, Z.; BARAN, M.; ZELENÁK, I. Comparison of two in vitro fermentation gas production methods using both rumen fluid and faecal inoculum from sheep. Animal Feed Science and Technology, Amsterdam, v. 123, n. 1, p. 81-94, 2005.

WILSON, J. R. Cell wall characteristics in relation to forage digestion by ruminants. Journal of Agricultural Science, London, v. 122, n. 2, p. 173-182, 1994.

YANG, W. Z.; SON, Y. S.; BEAUCHEMIN, K. A. Effects of exogenous enzymes on ruminal fermentation and degradability of alfalfa hay and rice straw. AsianAustralasian Journal of Animal Science, Gwanak-gu, v. 24, n. 1, p. 56-64, 2011. 
